\title{
Customer Lifetime Value Model in Perspective of Firm and Customer: Practical Issues and Limitation on Prospecting Profitable Customers of Hypermarket Business
}

\author{
Abdul Manaf Bohari \\ PhD Candidates, School of Humanities, Universiti Sains Malaysia, Malaysia \\ $\&$ \\ Senior Lectures, UUM College of Business, Universiti Utara Malaysia \\ Tel: 60-19-414-3648Ｅ-mail: manafdr@uum.edu.my; abdmanaf.bohari@yahoo.com \\ Professor Dr Ruslan Rainis \\ Professor, School of Humanities, Universiti Sains Malaysia, Penang 06010, Malaysia \\ Dr Malliga Marimuthu \\ School of Management, Universiti Sains Malaysia, Malaysia
}

Received: January 4, 2011 Accepted: March 4, 2011 doi:10.5539/ijbm.v6n8p161

\begin{abstract}
Most of business scholars claim customer lifetime value is the top priority issues in the world wide business operation includes for hypermarket business setting. Theoretically, prospecting lifetime value of customers in the marketplace is the main platform for determine how long the hypermarket can survive, at lease 3 to 5 years in future. In fact, customer lifetime value is become top strategic issues during the global meltdown economy because of it major affects on hypermarket profitability, both for current and future of business. Practically, there are two main streams for estimating lifetime value of customers, as identified as firm perspective and customer perspectives. As implication, there are arising some practical and implementation issues on it. The paper is purposely for discussed customer lifetime value model issues faced by the two main streams perspectives. Specifically, limitation of both perspectives is highlighted by using the hypermarket business as environment setting of discussion. In addition, some suggestion was point-out to tackle the problems.
\end{abstract}

Keywords: Lifetime value, Customer, Profitable, Hypermarket business

\section{Introduction}

Most of business scholars claim customer lifetime value (CLV) is the top priority issues in the world wide business operation includes for hypermarket business setting. Theoretically, prospecting lifetime value of customers in the marketplace is the main platform for determine how long the hypermarket can survive at lease 3 to 5 years in future. In fact, customer lifetime value is become top strategic issues during the global meltdown economy because of it major affects on hypermarket profitability. Practically, there are two main streams for estimating lifetime value of customers, as identified as firm perspective and customer perspectives. As implication, there are arising some practical and implementation issues on it. The paper is purposely for discussed customer lifetime value issues by using the two main streams perspectives as a research framework. Specifically, capabilities and limitation of both point of views is highlighted by using the hypermarket business as environment setting.

CLV is 'the top hot model' for estimating the profitability of the business, mainly aimed to predicting how long the relationship of customers and business will alive. American Marketing Association (2006) noted the study of CLV is becoming significantly more important, both in research and in practice. Lun and Tang (2008) believed CLV has been important research topics for a long time and similarly, Venkatesan and Kumar (2004) mention CLV is a useful for provided a forward-looking picture of maximizing firm profitability. Meanwhile, Holbrook (1994) cited that most of CLV research stream is aims at developing and maintaining profitable business relationships with selected customers. In another view, Gupta, Lehmann, and Stuart (2004) noted valuing CLV is vital important to makes it feasible to value firms, including high-growth firms with negative earnings. Here, the most critical aspect of a CLV firm is refers to its customers. In addition, Abdul Manaf Bohari, Ruslan and Malliga (2009) noted managing profitability in business has taken on a particular role, especially in the onset of the economic meltdown, as well as the late 1980s, 1998 and currently 2008. The performance of business can be 
improved by reduce costs of production, number of employees, operation costs, and many more. However, in practice, prospecting CLV become more complicated because most of CLV traditional model unable to produce suitable solution of CLV on current issues that have exist in the current marketplace. Even, traditional model also, sometime, have limited ability to suggest reasonable explanation on the result of CLV, especially for big size of business as such hypermarket business.

Technically, CLV is defined as the discounted value of the future profits yielded by a customer to the company. However, the issue is to predict the future profits when the timing and the profit of future transactions is not known, chaos and unpredictable because of involved with factors surrounding marketplace. Scholars Mulhern (1999) and Bell, Deighton, Reinartz, Rust, and Swartz (2002) identified non-contractual setting as one of the barriers for generating good results. However, similarly, contractual setting environment is also faced the same problems as well as identified before. The need for prospecting CLV with precise results are become more critical and created high attention form scholars, as well as Berger and Nasr (1998), Reinartz and Kumar (2003), Gupta and Lehmann, (2003), Gupta, Lehmann and Stuart (2004), Venkatesan and Kumar (2004), Rust, Lemon, and Zeithaml (2004), Gupta and Zeithaml (2006), Shah, Rust, Parasuraman, Stealin and Day (2006), Wangenheim and Bayon (2007), Graf and Maas (2008), Glady, Baesens and Croux (2009), Therefore, in future, Abdul Manaf Bohari et. al., (2009) suggest further study should focus on exploring and testing other non-financial based variables, for incorporating with CLV variables. Some of them are location and accessibility. For examples, Glady, et al, (2009) tested some socio-demographic explanatory variables into CLV prediction. The studied shows the dependence between the number of transactions and the average profit per transaction, socio-demographic regresses will be taken into account as well.

\section{CLV in Perspectives}

Since CLV concept introduced to the market in 1930s, a multitude of CLV model and approaches have emerged, with variation in definitions, terms, and analogies. To the best of knowledge, there are two theoretical differentiable approaches for prospecting CLV:

\subsection{CLV from firm perspective}

From firm perspective, the value of the customer is central activity for the business. The mainly objectives is to evaluate how attractive individual customers or customer groups are from a company perspective. This approach became a popular research topic in the last few years, as well as noted by researchers. As example, Reinartz and Kumar (2003) have done their work on profitable lifetime duration; Rust, Lemon, and Zeithaml (2004) focused on customer equity and Krafft, Rudolf and Rudolf-Sipotz (2005) on valuation of customers in growth companies.

The firm perspectives on CLV are more toward accounting or financial based approaches with highly consideration on financial based instrument and assessments, as well as costs, expenses, investment, rate, and any kind of tangible values regard to business operations. Mostly, it involved 'profit and losses' with highly depend on every single variable as explain before.

\subsection{CLV from customer perspective}

The focus is on value generated by a company's product or service as perceived by the customer or the fulfillment of customer goals and desires by company products and/or services. The CLV can be defined as the overall value of the current and future customer base, specifically form ground view of consumer's society. In this fact, CLV is divided into two major categories, called Perceived Customer Value (PCV) and Desired Customer Value (DCV). According to Flint, Woodruff and Gardial (1997), PCV focuses on the assessment of specific benefits and sacrifices, while DCV is concentrates on customer's needs and desires. DCV is independent of use-specific experience and more enduring than PCV.

Table 1 show some of CLV research works that have done with regard to these two main streams. From Table 1 we found that CLV from firm perspective is more concentrates on how to use CLV to maximizing firm profitable. In contract, form customer perspective, there are more on how to strengthening customer itself to spurs CLV performance. Here, a gap between these two perspectives has created and then leads to raise some of common CLV practical issues as discussed onward.

\section{Insert Table 1 here}

\section{Practical Issues of CLV in Applied for the Hypermarket Business Setting}

Hypermarket is one of important segment within retailing sector with highly involve huge and various types of customers. Hypermarket is a critical segment of business because it has highly contribution to national growth, as cited by Mui, Nurwati, and Ahmad (2003). More than 25 years ago, Lusch (1982) cited that retailing, includes Hypermarket which operates in an open milieu in cities is continuously subject to various external forces including customer behaviour, rival competition, legislative framework, technological advancement, and changes in societal status and values. Abdul Manaf Bohari et. al., (2009) discussed hypermarket business is one of market segmentation in Malaysia that has involved with multicultural customers needs and potentially generates different value of CLV among them. Because of that, hypermarket still need to manage their own customers especially for creates healthy CLV for make batter performance in future operations. 
Here, some of CLV practical issues in contact of hypermarket business are discussed, as below.

\subsection{Chaos of Value}

The value of an individual customer is important for the search of the most valuable ones, which deserve to be closely followed, and for the detection of the less valuable ones, to which the company should pay less attention. However, almost all the time, hypermarket should remind that the customers are an important asset, and as such, have to be precisely valuated, as cited by Glady, Baesens and Croux (2009). In certain location, hypermarkets take hard initiative to spurs their profit with attention on maximizing their customer satisfactions and value. This could be happen because of the manager has always concern on cost and revenues that bear on them; with less attention on what actual their customers get from transaction with them. From customer point of view, the hypermarket actually high possible to lost their money if their transactions were not making them satisfied. In this case, hypermarket must understand what actually CLV that perceived of their customer. Understanding CLV on customer point of view is not easy because it always unable to counted, as well as counting the profit and cost. In addition, from hypermarket point of view, they are assumed that there are not lost anything as well as profit-cost well counted in balances value. Here, the business has chaos on what actually contributes to their healthy CLV, especially on part of non profit based accounting measurement as such duration of customer stay buys from them.

\subsection{Contradiction of Benefits}

Technically, by measuring the profitability of segments and managing customer relationships based on customer value, both the customer and company win (Epstein, Friedl \& Yuthas, 2008). In practice, most of hypermarkets initiate to promote their products by using specific marketing tactics with hope to spur their sales, either weekly or monthly. Hypermarkets through marketing department will setting some stimulus, as such discount price more than 70 percent for selected items to encourage customer to come over. Some of hypermarket offers special price on specific event, as well as Year End Sale, Countdown Sale, Back to School Campaign, and many more. However, in perspective of customer's, the biggest unsolved question is what actually they from their purchased. Some of products that offers to them, of course low price, but questionable in quality matter. Some of product offers in extreme discount price, as example ninety percent discount, but, questionable on benefits that customer gain from them. Here, CLV of customer should be the first signal to determine either CLV of hypermarket has positive or negative impacts on their performance. Contradicts of benefits between hypermarket business with customer will create a gap of need between them, current and future prospect of business lifetime.

\subsection{Less Aware of Unprofitable Customer}

Mostly, CLV instrument is developed with highly attention on financial items, as such interest rate, cost of capital, average gross contribution, and so on. For example, Kumar and Reinartz (2005) through Share-of-Wallet (SOM) model have defined CLV as the proportion of category value accounted for by a focal brand or a focal firm within its base of buyers. In the real marketplace, this Share-of-Wallet model has lacking of information, as cited by Abdul Manaf Bohari et. al., (2009) and information about a customer's spending with competitors is not normally available with the firms even the number of competitors has not accounting onto it. Normally, this type of information can obtain from primary market research or surveys administered to a representative sample of firm's customers. In adition, the results from SOM are not applicable for projecting onto the current customer on the geographical area. Specifically, in the case of hypermarket business, lack of information is still critical because hypermarket need to handle a large of customer databases, which is every time chance faster than their action. Here, the hypermarket has limitation to ignore unprofitable customer, especially customer's who has less on frequency and spending value on hypermarket product purchases.

\subsection{Too Depend on Customer Database}

Most of CLV model are highly depend on customer database where as increased on daily basic whereas generated from information via credit card, debit card and membership card. However, as implication, too much depend on customer database for prospecting CLV will lead them to un-aware about customer who has not available in their database customer, as identified as free customer by Abe (2009). The hypermarket will face a problem on free customer CLV because most of free customer information are not available in their database. The situation will become more serious if most of hypermarket revenues are generated from this category of customer. The hypermarket is not able to predict accurately on how strong free customer will create impacts on them profit, both short and long terms. Thus, because of CLV results are mostly develop for customer database that available to them, here, we found that hypermarket are facing challenge from free customer. The traditional CLV model is not applicable for used to predict a contribution of free customer to hypermarket. As implication, new alternative must have to find to cover this part of customer because they also contribute to hypermarket success.

\subsection{Dramatically Change in the Marketplace}

The dramatically chance in the marketplace was exists in every time, day and week. The change is caused by many factors, as well as change in demographic, lifestyle, and socio-economic status, current scenario of international trend, and so on. However, the most important factor on estimating CLV is customer itself. 
However, sadly, CLV model was not enough sensitive detect to any changes in the marketplaces. For example, hypermarket has not ability to understand why customers change their purchasing pattern if they too depend on customer database. Financial instrument as well as chunk rate, interest rate, retention cost, periodic revenue and so has no direct link with variable that exist in the marketplace. Recently, Janiak (2009) viewed that customer intensely value-oriented is one of the reasons why business continuously survive and maintain their performance and profitability from year to another years. Consumers will be intensely value-oriented in 2009, even more so than in the recent past. In an environment of slow growth by the year 2009, the business will need to focus on building market share via business models that are more responsive, adaptable, and efficient with resources and assets. The business also should evaluate opportunities to drive short-term, bottom-line results.

\section{Limitation of CLV Approach}

\subsection{CLV of Firm Approach}

CLV is a key element of the company perspective, which is the present value of all future profits generated from customer in the marketplace, as cited by Gupta and Lehmann (2003). Mainly, one of the CLV model in accounting approach is Activity-based-Costing model or $\mathrm{ABC}$ model. The $\mathrm{ABC}$ model basically utilize to analysis and view operations of the business from a process perspective. It wan helpfully in identify the levers and sources that drive profitability or income even future potential sources for generate income to the business. However, $\mathrm{ABC}$ approaches are derive from accounting based instrument, as well as tangible and in-tangible cost that counting all the costs related to every activity by the business. The $\mathrm{ABC}$ model it is not take into accounting any non accounting or financial instruments as their parameters. In addition, the $\mathrm{ABC}$ model has no enough capabilities in visualizes the actual profitable customers in specific location of marketplace because the model not takes into account factors that related to customer. In addition, the ABC model has no capabilities to analyze the direct cost bear on customers, such as transportations, parking and switching costs that always played by the customers on daily purchasing activity.

Financial based model as such Return on Investment (ROI) model is a financial based CLV model for calculation and justifications the financial results of an investment. The ROI model is straightforward used for define a given use of money or resources in an enterprise and then the ROI be able to predicts how much profit or cost saving is realized. The ROI model is depend on hard metrics, usually money spent and money saved or gained in specific period of financial term. Alternatively, another financial based model as such Present Value (PV), Net Present Value (NPV), Return on Investment and Internal Rate of Return (IRR) has been used to calculate purely financial ROI and all of it is financial based instrument is estimated value on the monetary point of views. Although the financial version of CLV model has successful demonstrated a long life-cycle of customer, but, the model still lack of ability on estimate what actually relay on customer value in the reality of the marketplace. Moreover, most of financial CLV has no relationship with spatial platform, event not friendly with spatial variables, whereas important to understand CLV from customer point of view.

One of the popular and latest approach to calculating CLV is by utilizing model, called Customer Equity Model (CE) as describe by Rust, Lemon and Zeithaml (2004). Fundamentally, CLV can calculate thoroughly CE Model of a firm as;

$$
C E=\sum_{i=1}^{I} \sum_{t=1}^{T} C M_{i t}\left(\frac{1}{1+\delta}\right)^{t}
$$

Where

$\mathrm{CE}=$ customer equity of customer base in $\$$ (sum of individual lifetime values)

$\mathrm{CM}=$ Contribution margin in time period $\mathrm{t}$

$\delta=$ discount rate

$\mathrm{i}=$ customer index

$\mathrm{t}=$ time period

$\mathrm{T}=$ the number of time periods for which $\mathrm{CE}$ is being estimated.

By applied this CE model, the CLV measure gives the economic value of a firm and then, average CLV can calculate by dividing CE by the number of customers. However, here, there are no spatial items or variable that used for counting CLV of every customer, although non monetary items such as location and accessibility are vital important of contributes to the performance of overall CLV.

Secondly, another approach of CLV has introduced by Berger and Nasr (1998) and applied by Kumar and Ramani (2004). By applied this model, the average CLV of every customer is projected from the lifetime value of a cohort or customer segment. Thus, this is segment based approach and by the way, the average CLV of a customer in specific cohort, for examples the first cohort can then be expressed as;

$$
C L V_{1}=\sum_{t=0}^{T}\left[\frac{(G C-M)}{(1+d)^{t}} r^{t}\right]-A
$$


Where

$\mathrm{r}=$ rate of retention

$\mathrm{d}=$ discount rate or the cost of capital for the firm.

$\mathrm{t}=$ time period

$\mathrm{T}=$ the number of time periods considered for estimating CE.

$\mathrm{GC}=$ the average gross contribution.

$\mathrm{M}=$ marketing cost per customer

$\mathrm{A}=$ the average acquisition cost per customer

Briefly, this approach takes into account on the three items, as well as average gross contribution (GC), the average acquisition cost per customer (A), and marketing cost (M) per customer where as focused on costs and revenues. Meanwhile, the retention rate, $r$ is the average retention rate for the specific cohort and is assumes as a constant value over a period. One of constrain by applied this model is that customers leave the relationship with the firm in different points. In the marketplace, the time of retention probabilities vary across, either among customers, location and time. This means that a retention probability is not really utilized in estimating CLV. Moreover, the most important point is how to visualize the CLV value as close to real situation. In addition, statistical or mathematical equation is unable to visualize CLV result because lacking of geographical platform.

In another point of view, CLV is calculated as the sum of cumulated cash flows discounted by applied the Weighted Average Cost of Capital (WACC) formula and this is refers to a customer over his or her entire lifetime with the company. By using individual approach, this model is a function of the three items, such as predicted contribution margin, the propensity for a customer to continue in the relationship, and the marketing resources allocated to the customer. Structurally, the model has two main components with focused on future contribution margin and future costs. To calculate the future margin from single customer, a firm should know the probability that the customer continues to do business with the firm in future time periods or probability of customer being active, $\mathrm{P}$ (Active). This is disadvantages of the model because probability of customer is always failed to predictable accurately. Specifically, item as time periods should be spatially matter because it was determine by spatial variables, such as demographic backgrounds of every single customer, location, accessibility and many more. In general, Weighted Average Cost of Capital (WACC) CLV can be expressed as below:

$$
C L V_{i}=\sum_{t=1}^{T} \frac{\left(\text { Future contribution } \text { margin }_{\text {it }}-\text { Future } \cos t_{i t}\right)}{(1+d)^{t}}
$$

Where

$\mathrm{i}=$ customer index,

$\mathrm{t}=$ time index

$\mathrm{T}=$ the number of time periods considered for estimating CLV

$\mathrm{d}=$ discount rate.

Overall, in perspective of firms, CLV is identified as how long customers will engage, make a transaction and repeat transactions with them. As longest as customer buying and spending the money on product and or services, it generally indicates that firm's profitability will be gradually growth and continuously generate profit. In fact, most of items for estimating CLV of firm are sources from financial or accounting items, with highly consideration on costs and profits. Here, new construct or item of measurement of CLV should introduce to support the existing CLV model.

\subsection{CLV of Customer Approach}

Valuing customers in the marketplace is a central issue of any commercial activity, as discussed by Glady, Baesens and Croux (2009), Epstein, Friedl and Yuthas (2008), Baum and Singh (2008), Long, Trouve, and Blackmore (2005), and Accenture (2007). Most of scholars such as Baum and Singh (2008), Berman and Evans (2008), Long, Trouve, and Blackmore (2005), and Accenture (2007) believe that customer is crucial part that contributes to retailer profitability for a short and long term business life cycles. Baum and Singh (2008) noted that understanding crucial customer touch of point and the most important expectations of customer are first step in establishing high-quality and effective customer services. Beside that, the quality of customer service and the overall customer experience are important factors consumers used in choosing company product over others. Similarly, Accenture (2007) points out that today's consumers are more demanding and also more diverse. These trends have created a consumer who is also more empowered compared to before. In addition, Berman and Evans (2007) believe that loyal customers are the backbone of a business and for that, four factors must to keep when manage customers are customer base, customer services, customer satisfaction and loyalty programs and defection rates. Specifically, retailers must regularly analyze their customer's base with finally to identify the 
retailer's core customers or its best customers. Overall, CLV in perspective of customers are determining by marketplace environment issues either directly or indirectly influence on customers of choosing the destination of shopping.

The value of an individual customer is important for the detection of the most valuable ones, which deserve to be closely followed, and for the detection of the less valuable ones, to which the company should pay less attention. However, almost all the time, firms should remind that the customers are an important asset, and as such, have to be precisely valuated (Glady, Baesens \& Croux, 2009). Meanwhile, Epstein, Friedl and Yuthas in (2008) indicated by measuring the profitability of segments and managing customer relationships based on customer value, both the customer and company win. Orienting an organization around measurement and management of customer profitability can take place immediately, or it can take many periods, implementing these strategies one step at a time, and adjusting and refining along the way. Meanwhile, CLV in perspective of customer's are viewing in different ways, compared to CLV of Firm, which focused on CLV totally on customer. In fact, customers have ability to determine how long and how much there is wailings to spend their money for transaction that they made with the firms. Here, CLV from firm perspective and customer perspective will be divest and expand in different ways, event there have different model of prospecting CLV.

Traditionally, there are three common models for estimating CLV from customer perspectives that are RFM, Share-of-Wallet and Past Customer Value. All these models practically derive the value of CLV based on what actually experienced by the customer in the marketplace. The first one is RFM method, as introduced by Bult and Wansbeek (1995), where RFM is stand for Recency, Frequency, and Monetary. In fact, this model utilizes these three metrics to evaluate customer behavior and customer value. Thus, item Recency is a measure of how long it has been since a customer last placed an order with the company; item Frequency is a measure of how often a customer orders from the company in a certain defined period, and lastly, item Monetary value is the amount that a customer spends on an average transaction. The RFM model is shows below:

$$
\mathrm{CLV}=\mathrm{R} \times \mathrm{F} \mathrm{X} \mathrm{M}
$$

Where

$\mathrm{R}=$ Recency of how long it has been since a customer last placed an order with the company.

$\mathrm{F}=$ Frequency of how often a customer orders from the company in a certain defined period.

$\mathrm{M}=$ Monetary Value of amount that a customer spends on an average transaction.

Beside that, commonly, there are two methods are used for computing the RFM model. The first method involves sorting customer data from the customer database, based on RFM criteria and grouping them in equal quintiles and analyzing the resulting data. The second method involves the computation of relative weights for each R, F, and M. Here, some statistical techniques, as well as regression model can use for it. Then, those weights are used for calculating the combined effects of RFM. RFM can be considered as the sum of the weighted recency, frequency, and monetary value scores for a customer. However, RFM methods are not able to visualize the CLV value geographically in the marketplace. To the best of knowledge, this is because of the RFM model never tested into geographical platform for producing the actual value of CLV. Even, there is less attention of applied RFM for free customer whereas important parties to hypermarket as important as their regular customers that has membership card.

Share-of-Wallet (SOW) model is the second model that can be used for estimating the CLV of each customer. Kumar and Reinartz (2005) defined SOW as the proportion of category value accounted for by a focal brand or a focal firm within its base of buyers. The SOM can use both for aggregate and individual level. At an individual customer level for example, SOW is defined as the proportion of category value accounted for by a focal brand or a focal firm for a buyer from all brands that the buyer purchases in that category. It indicates the degree to which a customer meets his needs in the category with a focal brand or firm. It is computed by dividing the value of sales (S) of the focal firm (j) to a buyer in a category by the size-of-wallet of the same customer in a time period. SOW is measured in percentage. Shortly, formula for SOM is:

$$
\mathrm{s}_{\mathrm{j}} / \sum_{j=1}^{J} \quad \mathrm{~s}_{\mathrm{j}}
$$

Where

$\mathrm{S}=$ sales to the focal customer

$\mathrm{j}=$ firm

$\sum^{J} \quad=$ summation of the value of sales made by all the $J$ firms that sell a category of products to a buyer.

In the real marketplace, by applied this model has lacking in term of information. The information about a customer's spending with competitors is not always available with the firms even the number of competitors has 
not accounting onto it. Normally, this is obtained from primary market research or surveys administered to a representative sample of firm's customers. However, the results of CLV SOM are not applicable for projecting into the geographical area.

The third model for valuing CLV is past customer value model (PCV model) which is built on the assumption that the past performance of the customer (transaction or buying) indicates their future level of profitability and an extrapolation of the results of past transactions is a measure of customer's value in the future. The value of a customer is determined based on the total contribution (towards profits) provided by the customer in the past. The contributions from past transactions of every customer are adjusted for the time value of money and the cumulative contribution till the present period of the past customer value of customer. PCV can compute using the following formula;

$$
\sum_{t=1}^{T} G C_{i t} *(1+r)^{t}
$$

Where

$\mathrm{i}=$ number representing the customer

$\mathrm{r}=$ applicable discount rate

$\mathrm{T}=$ number of time periods prior to current period when purchase was made

$\mathrm{GCit}=$ Gross Contribution of transaction of the ith customer in time period, $\mathrm{t}$.

However, this model is lacking of detecting the location of a single customer in the geographical location. Although the model are using customer data base for prospecting CLV, however, is still not good enough. This is because of the model is not able to presenting the CLV of customer in the market place, as well as other CLV model.

In addition, there are many CLV model produced specifically for estimating CLV of customer, either, from firm perspective or customer perspective. For that, Table 2 shows an overview of items that normally used for prospecting CLV.

\section{Insert Table 2 here}

For a long direction, CLV always view in term of financial matter and seeks to maximize profit by analyzing customer and business cycles to identify and target customers with the greatest potential net value over time. It brings mean that anciently CLV is totally build-up on financial or accounting instrument and calculation without considering the insight of customer on what they want and need. Lucas (2008) stated that CLV is firstly espoused in the 1930s. The CLV metric was originally designed to assess the net present value of a customer's future spending. But in the 1990s marketing gurus like Don Peppers and Martha Rogers added their own take on CLV, throwing more-conceptual items into the mix. Overall, the goal of CLV is straightforward whereas separate the truly profitable client from the barely profitable, and allocate resources accordingly. Thus, customer profitability is a customer-level variable which refers to the revenues less the costs which one particular customer generates over a given period of time. In the end, key components of CLV are Risk, Revenue, and Churn. Therefore, for calculating CLV, is requires Risk, Revenue and Churn forecasts separately, jointly or conditionally.

\section{Discussions and Conclusion}

Hypermarket business is one of the most promising fields of business to utilize spatial technology. Commonly, one of reason to apply spatial technology in hypermarket business was to visualize and mapping any applicable results of marketing research, includes CLV of every customer in the marketplace. Nowadays, after dramatically change in spatial technology trend, more and reliable analytical operations are performed within a spatial environment. The growing interest in spatial applications among business people were rise sharply, inclusively in many kind of commercial business. The diffusion of spatial technology has reached the commercial sector, but it not in all activities will be equally affected by the GIS sophistication. It is important to note that the way of spatial technology is used will even differ within a commercial organization. Obviously, Pick (2008) shows that important aspects of spatial data are its cost, ownership, security, privacy, data quality, and currency/updating. In advance, scope of spatial and associated attribute data is vast and covers the range of business activities in multiple industries. In advance, Abdul Manaf Bohari et al., (2009) suggests some intensive research must do on how to use and integrated spatial and non-spatial data into GIS platform especially for prospecting CLV of customer in the real marketplace. This initiative will improvised an approach of estimating CLV whereas different compared to CLV of firm and individual perspectives.

\section{Acknowledgment}

We would like to thanks UNIVERSITI SAINS MALAYSIA for funding this research project through the USM-RU-PGRS Research Grant.

\section{References}

Abdul Manaf Bohari, Prof Ruslan Rainis \& Malliga Marimuthu. (2009). Geographical Information Systems 
Potential Uses in the Global Retailing Industries. Proceeding of the Third Asia Pasific Marketing Conference 2009. Organized by Faculty of Economy and Business, Universiti Malaysia Sarawak, Damai Beach Resort, Kuching, Sarawak, Malaysia. 9th - 11th December 2009.

Accenture. (2007). Accenture 2007 global customer satisfaction survey report. Chicago: Accenture Inc.

Bastedo, M. (2008). Business value of GIS in a complex organization. Proceding of 2008 ESRI Business GIS Summit. ESRI Business GIS Summit. April 27- 30, 2008, Chicago, Illinois.

Baum, M., \& Singh, I. (2008). Winning the customer service battle. Chicago: A.T. Kearney, Inc.

Bejou, D., Keiningham, T.L., \& Aksoy, L. (2007). Customer lifetime value: Reshaping the way we manage to maximize profits. New York: The Haworth Press, Inc.

Berger, P. D., \& Nasr, N. I. (1998). Customer lifetime value: Marketing models and Applications. Journal of Interactive Marketing, 12(Winter) 17-30.

Berman, B., \& Evans, J.R. (2007). Retail management: A strategic approach. New Jersey: Pearson Prentice Hall. Clancy, G. (2008). Best practices for implementing a successful GIS project. Proceding of 2008 ESRI Business GIS Summit. ESRI Business GIS Summit. April 27- 30, 2008, Chicago, Illinois.

Environmental System Research Institute (ESRI). (2002). ArcView business analyst: The value added. An ESRI White Paper June 2002. California: ESRI.

Environmental System Research Institute (ESRI). (2007). GIS for retail business. GIS Best Practice (Febuary 2007). California: ESRI.

Epstein, M.J., Friedl., M., \& Yuthas, K. (2008). Managing customer profitability: Determine which customers are most valuable to your organizaton. Journal of Accountancy (Business and Industry). Harvard Business School: December, 2008.

Fabel, M., Sonnenschein, M., Sester, A., \& Golestan, L. (2008). Customer energy: The empowered consumer is revolutionizing customer relationships. Chicago: A.T. Kearney Inc. (Marketing and Communications).

Fader, P. (2009). Understanding customer lifetime value: Conceptual overview and implementation in excel. Pre-Conference Workshops. Forecating Summit 2009. Hilton in the Walt Disney World Resort, Orlando, Florida. Febuary 23-25 2009. [Online] Available: http://www.forecasting-summit.com/pre (March 30, 2009)

Gilbert, S.J. (2007). How do you value a "free" customer?. Research \& Ideas. Boston: Harvard Business School

Glady, N., Baesens, B., \& Croux, C. (2009). A modified pareto/NBD approach for predicting customer lifetime value. Expert Systems with Applications, 36, 2062-2071.

Hoffman, J.L., Wildman, R., Rebollo, J.M., Clarke, A., \& Simoes, V. (2008). Retailing in a global marketplace to achieve high performance. Chicago: Accenture Inc.,

Kumar, V., \& Ramani, G. (2004). Taking customer lifetime value analysis to the next level. Journal of Integrated Communications, 27-33.

Kumar, V., \& Reinartz, W. J. (2005). Customer relationship management: A databased approach. New York: Wiley.

Laudon, K., \& Laudon, P. (2008). Management information systems. New Jersey: Prentice Hall.

Long, J., Trouve, O., \& Blackmore, K. (2005). Finding and keeping your best customer through customer-centric retailing. Chicago: Accenture Inc.,

Longley, P.A., Goodchild, M.F., \& Rhind, D.W. (2005). Geographic information systems and science. New York: John Wiley and Sons.

Lucas, A. (2008). Customer Lifetime Value Modelling. Rhino Risk Ltd.

Lusch, Robert F. (1982). Management of Retail Enterprises. Boston: Kent Publishing Company

Miller, F.L. (2007). GIS tutorial for Marketing. Adelaide: ESRI Australia Pty Ltd.

Muharam, S. (2001). Wet and Traditional Market Profile in Jakarta. [Online] Available: http://www.smfranchise.com/news/wetjkt.htm ( accessed: 6 January 2003)

Mui, L.Y., Nurwati, B., \& Ahmad, A.Ghafar. (2003). Retail Activity in Malaysia: From Shophouse to Hypermarket. the Pacific Rim Real Estate Society 9th Annual Conference, 20-22 January 2003, University of Queensland and Queensland University of Technology, Brisbane, Australia.

Pick, J.B. (2008). Geo-Business: GIS in the digital organization. Singapore: John Wiley \& Sons, Inc.,

Rust, R.T., Lemon, K.N., \& Zeithaml, V.A. (2004). Return on marketing: Using customer equity to focus marketing strategy. Journal of Marketing, 68, 109 -127.

Toppen, F., \& Wapenaar, H. (1994). GIS in business: Tools for marketing analysis. The Hague: EGIS Foundation. 
Table 1. CLV Research Works based on Two Main Streams

\begin{tabular}{|c|c|}
\hline & \\
\hline $\begin{array}{l}\text { - Flint, Woodruff \& Gardial (1997) - CLV of value } \\
\text { chance. } \\
\text { - Berger \& Nasr (1998) - Marketing model of CLV. } \\
\text { - Reinartz \& Kumar (2003) - CLV and profitable } \\
\text { lifetime duration. } \\
\text { - Rust, Lemon, \& Zeithaml (2004) - Customer } \\
\text { equity. } \\
\text { - Krafft, Rudolf, \&Rudolf-Sipotz (2005) - } \\
\text { Valuation of customers in growth companies. } \\
\text { - Berger, Eechambadi, George, Lehmann, Rizley \& } \\
\text { Venkatesan (2006) - CLV of shareholders. } \\
\text { - Bejou, Keiningham \& Aksoy (2007) - maximizing } \\
\text { the CLV future value. } \\
\text { - Aeron, Bhaskar, Sundararajan, Kumar \&Moorthy } \\
\text { (2008) - A CLV metric. } \\
\text { - Abe (2009) - Calculating single value of CLV. }\end{array}$ & $\begin{array}{l}\text { - Flint, Woodruff \& Gardial (1997) - DVC and } \\
\text { PCV. } \\
\text { - Blattberg \& Deighton (1996) - Customer } \\
\text { Equity. } \\
\text { - Gupta \& Lehmann (2003) - Customer as asset } \\
\text { for CLV. } \\
\text { - Gupta \& Zeithaml (2006) - Customer metric } \\
\text { and CLV performance. } \\
\text { - Ha \& Bae (2006) - Customer relationship and } \\
\text { CLV. } \\
\text { - Gilbert (2007) - CLV and free customer. } \\
\text { - Epstein, Friedl \& Yuthas (2008) - CLV and non } \\
\text { profitable customers. } \\
\text { - Graf \& Maas (2008) - CV of Current } \\
\text { Customers. } \\
\text { - Glady, Baesens \& Croux (2009) - CLV and } \\
\text { customer loyalty. }\end{array}$ \\
\hline
\end{tabular}

Table 2. An Overview of Items of the CLV Model (Firm and Customer based Approach)

\begin{tabular}{|l|l|}
\hline Items & Explanation \\
\hline Churn rate & $\begin{array}{l}\text { Refer to the percentage of customers who end their relationship with a } \\
\text { company in a given period and one minus of it is the retention rate. Most } \\
\text { CLV models are written using either churn rate or retention rate. Normally, } \\
\text { the assumption applied to the churn rate is constant across the life of the } \\
\text { customer relationship. }\end{array}$ \\
\hline Discount rate & $\begin{array}{l}\text { Refer to the cost of capital used to discount future revenue from a customer. } \\
\text { In some case, the interest rate is sometimes used as a proxy for discount rate. }\end{array}$ \\
\hline Retention cost & $\begin{array}{l}\text { Refer to the amount of money that has spend by firm in a given period to } \\
\text { retain an existing customer, include for customer support, billing, } \\
\text { promotional incentives, so on. }\end{array}$ \\
\hline Period & $\begin{array}{l}\text { Refer to the unit of time into which a customer relationship is divided for } \\
\text { analysis. The number of periods used is sometimes referred to as the model } \\
\text { horizon. However, CLV is a multi-period calculation. }\end{array}$ \\
\hline Periodic Revenue & $\begin{array}{l}\text { Refer to the amount of revenue that was collected from a customer in the } \\
\text { specific period. }\end{array}$ \\
\hline
\end{tabular}

